\title{
Urgences
}

\section{Sismique (extraits)}

\section{Pierre Morin}

Numéro 7, 2e trimestre 1983

URI : https://id.erudit.org/iderudit/025107ar

DOI : https://doi.org/10.7202/025107ar

Aller au sommaire du numéro

Éditeur(s)

Urgences

ISSN

0226-9554 (imprimé)

1927-3924 (numérique)

Découvrir la revue

Citer ce document

Morin, P. (1983). Sismique (extraits). Urgences, (7), 69-74.

https://doi.org/10.7202/025107ar

Ce document est protégé par la loi sur le droit d'auteur. L'utilisation des services d'Érudit (y compris la reproduction) est assujettie à sa politique d'utilisation que vous pouvez consulter en ligne.

https://apropos.erudit.org/fr/usagers/politique-dutilisation/
Cet article est diffusé et préservé par Érudit.

Érudit est un consortium interuniversitaire sans but lucratif composé de l'Université de Montréal, l'Université Laval et l'Université du Québec à Montréal. Il a pour mission la promotion et la valorisation de la recherche. https://www.erudit.org/fr/ 
PIERRE MORIN

\title{
Sismique
}

\author{
(extraits)
}




\section{TRÉPANATION}

Un arc de cercle carrément subtil

une voilette de tulle et des poutres de feu

dans cette voûte surplombée

je renverse la vapeur du concave je convexe vers le grossissement interne des choses amplification démagogique les couleurs se tonalisent les gammes se multiplient pour déteindre les sons repas musical

inextricablement sans arrière-pensée je fais I'historique du temps futur pour aimer... je vole pour respirer... je vis mais quand I'homme se tue et que I'espoir jaunit puisque la source se tarit et sèche 
j'hécatombe de haut

je grille-pain sur le balcon

je tire-bouchon d'un amour frénétique

je camion-remorque mon coeur en panne

et tout s'apaise en moi

le dieu me donne sa grâce

magnifiquement

et le chrome resplendit dans la poussière

le crapaud fait son chemin à travers les couleuvres

l'astronaute voit la terre une boule inchangée

les siècles se consument

à grands coups de massacres

I'homme s'annule

à grands coups de matraques

atomiques

et mardi succède à lundi

de la même façon que jadis

le dieu nous trompe inévitablement 


\section{INTERFÉRENCES}

Les échos inodores du silence imbécile des gens muets d'en avoir trop dit ces choses dites d'un ton monocorde

tiraillent les chaînes de paille qui protègent cette vie privée de sens ce désir de paix et d'ennui retrouvé le doux émoi chuintant des rencontres de mai I'amalgame des coeurs en fusion l'indifférence rance et rêche des gestes figés dont seules les ombres bougent

brinquebalant et mécanique le choc du savoir fer combustion externe de l'intérieur exubérant ces choses dites d'un ton monocorde dérangent la nuit paisible et les pleurs des enfants

qui voudraient se faire oublier 


\section{BLUES D'ARVIDA}

Des mots sidérurgiques

pour dire le métal de la chaleur humaine

électrolyse mégawatt brûlures

pour sentir la fumée

pour voir la terre consumée

pour être de ruines

des idées d'aluminium

sur des routes de verres cassés

auxquels j'ai bu

par lesquels j'ai rêvé

je construis ma route par des rêves alcoolisés

je débris 


\section{BUILDING}

J'entends déjà les milliers de respirations asthmatiques des cafetières chromées

dans ces cubicules cancéreux

lieux de pourriture géométrique et cloisonnée

cordé dans l'ascenseur

je descends vers l'abrutissement

se photocopier et se jeter au panier

cristalliser une apparence dégueulasse

et soudain

nu devant ces matricules de chèques de paye

je deviens libre

je suis intersticiel 